J. Dairy Sci. 98:517-531

http://dx.doi.org/10.3168/jds.2014-8437

(C) American Dairy Science Association ${ }^{\circledR}, 2015$.

\title{
The effect of dietary crude protein and phosphorus on grass-fed dairy cow production, nutrient status, and milk heat stability
}

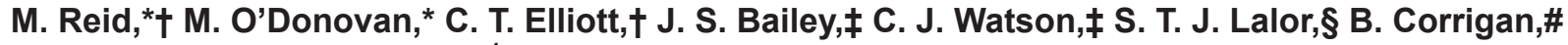 \\ M. A. Fenelon,\# and E. Lewis*1 \\ *Animal and Grassland Research and Innovation Centre, Teagasc, Moorepark, Fermoy, Co. Cork, Ireland \\ †Institute of Global Food Security, Queen's University Belfast, Stranmillis Road, Belfast BT9 5AY, United Kingdom \\ $\ddagger$ Agri-Food and Biosciences Institute, Newforge Lane, Belfast BT9 5PX, United Kingdom \\ $\S$ Crops, Environment and Land Use Programme, Teagasc, Johnstown Castle, Co. Wexford, Ireland \\ \#Food Chemistry and Technology Department, Teagasc, Food Research Centre, Moorepark, Fermoy, Co. Cork, Ireland
}

\begin{abstract}
Dietary crude protein $(\mathrm{CP})$ and phosphorus $(\mathrm{P})$ have the potential to alter dairy cow production, nutrient status, and milk heat stability, specifically in early lactation. This study examined the effect of supplementary concentrates with different $\mathrm{CP}$ and $\mathrm{P}$ concentrations on blood $\mathrm{N}$ and $\mathrm{P}$ status and on milk yield, composition, and heat stability. The concentrates [4 kg of dry matter (DM) concentrate per cow daily] were fed to grazing dairy cows (13 kg DM grass) during early lactation. Forty-eight spring-calving dairy cows were allocated to 4 treatments: high CP, high P (HPrHP; 302 g/kg DM CP, $6.8 \mathrm{~g} / \mathrm{kg}$ DM P), medium CP, high P (MPrHP; 202 $\mathrm{g} / \mathrm{kg}$ DM CP, $4.7 \mathrm{~g} / \mathrm{kg}$ DM P), low CP, high P (LPrHP; $101 \mathrm{~g} / \mathrm{kg} \mathrm{DM} \mathrm{CP}, 5.1 \mathrm{~g} / \mathrm{kg}$ DM P), and low CP, low P (LPrLP; $101 \mathrm{~g} / \mathrm{kg} \mathrm{DM} \mathrm{CP,} 0.058 \mathrm{~g} / \mathrm{kg}$ DM P), for 8 wk. Levels of $\mathrm{N}$ excretion were significantly higher in animals fed the HPrHP and MPrHP concentrates; $\mathrm{P}$ excretion was significantly lower in animals fed the LPrLP concentrate. Reducing the level of $\mathrm{P}$ in the diet (LPrLP concentrate) resulted in a significantly lower blood $\mathrm{P}$ concentration, whereas milk yield and composition (fat and protein) were not affected by either CP or $\mathrm{P}$ in the diet. The effect of the interaction between treatment and time on milk urea $\mathrm{N}$ was significant, reflecting the positive correlation between dietary CP and milk nonprotein N. Increasing supplementary CP and $\mathrm{P}(\mathrm{HPrHP})$ in the diet resulted in significantly lower milk heat stability at $\mathrm{pH}$ 6.8. The findings show that increasing dietary $\mathrm{CP}$ caused a decrease in milk heat stability, which reduced the suitability of milk for processing. The study also found that increasing dietary $\mathrm{CP}$ increased milk urea $\mathrm{N}$ and milk nonprotein $\mathrm{N}$. Increasing dietary $\mathrm{P}$ increased fecal $\mathrm{P}$ excretion. These are important considerations for milk processors and
\end{abstract}

Received June 3, 2014

Accepted September 24, 2014.

${ }^{1}$ Corresponding author: Eva.lewis@teagasc.ie producers for control of milk processing and environmental parameters.

Key words: supplementation, nitrogen, phosphorus, milk heat stability

\section{INTRODUCTION}

Temperate northern European countries, including Ireland, have a major competitive advantage in their ability to produce between 12 and $16 \mathrm{t}$ of grass DM/ ha over a 300-d growing season (Dillon et al., 2008). Ireland's dairy industry is largely based on grass as the primary nutrition source because this is the cheapest source of feed for milk production (Finneran et al., 2010). Maximizing the percentage of grass in the dairy cow diet has been shown to reduce overall milk production costs, thereby maximizing farm profitability (Dillon et al., 2008). Milk supply in Ireland is highly seasonal because calving dates on most farms coincide with the beginning of the grass-growing season (Dillon et al., 1997).

A seasonal pattern of grass growth leads to potential feed deficits in spring and autumn. The use of supplements such as concentrates and forages has an important role in filling the feed deficit at these times (Burke et al., 2008). Supplementing grazed grass diets in early spring, when grass is in short supply, has been shown to have a positive effect on milk yield and composition (Bargo et al., 2003). With the abolishment of milk quotas in the European Union in 2015, the Irish dairy industry is expected to expand (Dillon et al., 2008). One strategy for increasing milk production is to increase dairy cow numbers, which will result in increased stocking densities. This will necessitate greater supplementation in the spring and autumn.

Several studies (Forster et al., 1983; Kung and Huber, 1983) have shown that increasing dietary CP concentration has a positive effect on milk yield, milk protein concentration, and milk solids yield. Continued increases in dietary CP concentration, however, 
give diminishing returns in terms of milk production (Stockdale, 1995). It has been shown that offering a grass silage-based diet with a dietary $\mathrm{CP}$ concentration of only $150 \mathrm{~g}$ of $\mathrm{CP} / \mathrm{kg}$ of $\mathrm{DM}$ did not have negative effects on milk production (Castillo, 2001). Increased dietary $\mathrm{CP}$ increases the amount of protein degraded in the rumen. If RDP exceeds microbial needs, large amounts of ammonia are produced, absorbed into the blood, converted to urea in the liver, and ultimately excreted in the urine (Olmos Colmenero and Broderick, 2006). Although the majority of urea is excreted in the urine, some diffuses into the milk, where it is measured as MUN (Kauffman and St-Pierre, 2001), which can adversely affect milk heat stability, an indicator of milk processability. In spring, grass $\mathrm{CP}$ concentrations in Ireland tend to be greater than 20\% DM (O'Neill et al., 2013). Choosing a supplementary concentrate with low $\mathrm{CP}$ concentration may be an effective strategy for dairy farmers to reduce MUN and the amount of $\mathrm{N}$ excreted in urine.

Phosphorus fertilizer use in Ireland was $36 \%$ lower in 2012 compared with 2002 (DAFM, 2013). This reduction in $\mathrm{P}$ fertilizer use is associated with an overall reduction in grass $\mathrm{P}$ concentration (Schulte and Lalor, 2007). With grass being the primary source of nutrition in Ireland for dairy cows, any reduction in grass $\mathrm{P}$ concentration may lead to an overall reduction in the dietary $\mathrm{P}$ intake to levels below the recommended $0.35 \% \mathrm{P} / \mathrm{kg}$ of $\mathrm{DM}$ (NRC, 2001). Animal $\mathrm{P}$ status is important because $\mathrm{P}$ has more known functions in the animal body than any other mineral element (NRC, 2001). A P-deficient diet $(<0.35 \%)$ can negatively affect milk yield and milk composition (Wu and Satter, 2000). Approximately half of $\mathrm{P}$ in milk protein is complexed with CN (Satter, 2003). A reduction in dietary $\mathrm{P}$ may have negative consequences for $\mathrm{CN}$ and ultimately milk processability (Satter, 2003). Phosphorus, either excreted directly by livestock or applied to the land in the form of slurry or manure, can reach waterways and lead to nutrient enrichment (eutrophication) of both fresh and coastal waters (Smith et al., 2001). Improving $\mathrm{P}$ utilization by reducing $\mathrm{P}$ excretion while meeting dietary $\mathrm{P}$ recommendations is an important strategy to reduce the environmental footprint of dairy farms.

We hypothesized that an increase in dietary $\mathrm{CP}$ would increase MUN and have consequential negative effects on milk heat stability. Furthermore, we hypothesized that a reduction in dietary $\mathrm{P}$ would reduce milk $\mathrm{CN}$ concentration, reducing milk heat stability, and would reduce $\mathrm{P}$ excretion. The objective of the present study was to investigate the effects of offering supplementary concentrates differing in $\mathrm{CP}$ and $\mathrm{P}$ concentrations to grazing dairy cows in early lactation on milk yield, composition, and heat stability, and on $\mathrm{N}$ and $\mathrm{P}$ status.

\section{MATERIALS AND METHODS}

\section{Location}

The experiment was conducted at Teagasc, Animal and Grassland Research and Innovation Centre, Moorepark, Fermoy, Co. Cork, Ireland $\left(50^{\circ} 09^{\prime} \mathrm{N}, 8^{\circ} 16^{\prime} \mathrm{W} ; 35 \mathrm{~m}\right.$ above sea level). The area used was under permanent pasture with a predominantly perennial ryegrass ( $\mathrm{Lo}$ lium perenne L.) sward.

\section{Experimental Design and Animals}

The experiment was a completely randomized block design and was conducted between February 29 and May 1, 2012. Forty-eight lactating dairy cows (36 multiparous and 12 primiparous) with an average calving date of January 31, 2012, were used in the study. During the first week postcalving, the cows were offered approximately $15 \mathrm{~kg}$ of grass $\mathrm{DM} / \mathrm{cow}$ and $2 \mathrm{~kg}$ of concentrate DM/cow daily. Following this, and until the start of the experimental period, the cows were offered approximately $15 \mathrm{~kg}$ of grass DM/cow and $4 \mathrm{~kg}$ of concentrate DM/cow daily.

\section{Treatments}

The cows were blocked based on milk yield, milk protein concentration, milk solids yield, BW, and BCS, and were randomly assigned to 1 of 4 treatments: high $\mathrm{CP}$, high P (HPrHP), medium CP, high P (MPrHP), low CP, high P (LPrHP), and low CP, low P (LPrLP). Each treatment group was offered grazed grass and a different concentrate. The 4 treatment groups grazed independently in the same paddock separated by temporary strip wires. They were offered $13 \mathrm{~kg}$ of fresh grass $\mathrm{DM} /$ cow. Once daily, $4 \mathrm{~kg}$ of concentrate DM/ cow was offered. The HPrHP, LPrHP, and LPrLP concentrates were offered after morning milking on an outdoor winter feeding pad. Cows were secured with a self-locking stall swing (O'Donovan's Engineering, Coachford, Co. Cork, Ireland) to ensure that each cow received the correct concentrate allocation individually. The MPrHP concentrate was offered during morning milking via the Dairymaster feed delivery system (Dairymaster, Causeway, Co. Kerry, Ireland). The MPrHP concentrate was offered in the milking parlor because of the lack of available space in the self-locking stall swing. The HPrHP concentrate was a $30 \%$ DM CP coarse feed containing $0.68 \%$ DM P. It was composed (\% DM) of $20 \%$ soybean meal, $20 \%$ distillers grains, $20 \%$ rapeseed, $18 \%$ barley, $15 \%$ citrus pulp, $5 \%$ liquid molasses, and $2 \%$ mineral mix. The MPrHP concentrate was a $20 \%$ DM CP pellet containing $0.47 \%$ DM 
P. It was composed (\% DM) of $30 \%$ barley, $20 \%$ soy hulls, $14 \%$ rapeseed, $10 \%$ beans, $10 \%$ distillers grains, $6 \%$ liquid molasses, $5 \%$ citrus pulp, $3 \%$ mineral mix, and $2 \%$ calcined magnesite. The LPrHP concentrate was $10 \%$ DM CP coarse citrus pulp containing $0.51 \%$ DM P. It was composed (\% DM) of $94 \%$ citrus pulp and $6 \%$ dicalcium phosphate. The LPrLP concentrate was $10 \%$ DM CP coarse citrus pulp containing $0.006 \%$ P. It was composed of $100 \%$ DM citrus pulp. The energy, per kilogram of DM, of the diets formulated for the HPrHP, MPrHP, LPrHP, and LPrLP was 1.13, 1.12, 1.13, and 1.14 unité fourragère lait (UFL)/ $\mathrm{kg}$ of DM respectively, which is the equivalent of $1.92,1.90,1.92$, and 1.94 $\mathrm{Mcal} / \mathrm{kg}$ of DM (1 UFL $=1.7 \mathrm{Mcal}$ of $\mathrm{NE}_{\mathrm{L}}$; INRA, 1989). All of the concentrates were commercially available in Ireland and used by Irish dairy farmers. To gain differences in dietary $\mathrm{CP}$, the highest available $\mathrm{CP}$ concentrate and the lowest available $\mathrm{CP}$ concentrate were chosen from those available. The medium-CP concentrate (MPrHP) was intermediate and generally the most commonly used concentrate. During each day of the study, any concentrate not eaten by individual cows was weighed back to assess daily individual cow concentrate intake. Weekly samples of each treatment concentrate were collected and stored for chemical analysis.

\section{Grazing Management}

The grazing area for the experiment consisted of 18.37 ha divided into 28 individual paddocks with permanent fences. Paddocks were strip-grazed using temporary electric fences. The same quantity of grass, $13 \mathrm{~kg}$ of grass DM/cow per day, was allocated $(>4 \mathrm{~cm})$ to each treatment group. Pre- and postgrazing sward heights were assessed daily using a Jenquip rising plate meter (diameter $355 \mathrm{~mm}$; Jenquip, Feilding, New Zealand). Pre- and postgrazing sward heights were conducted by taking 50 height measurements/treatment per day. The daily grazing areas allocated for each of the treatments were determined by calculating the pregrazing herbage mass (PGHM). The PGHM ( $>4 \mathrm{~cm})$ was determined twice weekly by cutting 4 strips of grass per paddock $(1.2 \mathrm{~m} \times 10 \mathrm{~m})$ using an Etesia mower (Etesia UK Ltd., Warwick, UK). Ten measurements of sward height were taken pre- and postcutting using a rising plate meter (Jenquip). All mown grass from each cut was weighed and sampled $(\sim 0.3 \mathrm{~kg})$. A subsample of $0.1 \mathrm{~kg}$ was dried at $90^{\circ} \mathrm{C}$ for $16 \mathrm{~h}$ for $\mathrm{DM}$ estimation. The equivalent PGHM at ground level was calculated according to the estimations of PGHM at different heights above ground level as outlined by Pérez-Prieto and Delagarde (2012).

Weekly grass samples representative of that being grazed were manually collected using a Gardena hand shears (Husqvarna AB, Huskvarna, Sweden) from each treatment. The grass was cut to $4 \mathrm{~cm}$ in an attempt to gain samples representative of that being grazed by the cows. Cuts were taken at intervals along diagonal transects across treatment paddocks. Approximately 20 cuts contributed to the treatment sample. Samples were immediately frozen once collected. Samples were subsequently freeze-dried and passed through a 1-mm screen (Cyclotech 1093 sample mill, Foss Electric, Hillerød, Denmark) in preparation for chemical analysis.

Daily before grazing, LPrHP- and LPrLP-allocated areas were dusted with calcined magnesite (Cal-Mag, Nutribio Ltd., Co. Cork, Ireland) at an approximate rate of $210 \mathrm{~g} /$ cow per day to ensure an adequate supply of magnesium to prevent hypomagnesemia. The HPrHP and MPrHP treatment groups received their calcined magnesite via the concentrate.

\section{Chemical Analysis}

The CP concentration of the grass samples was determined using a Leco N Analyzer (Leco FP-528; Leco Corp., St. Joseph, MI). Ash was calculated by placing the samples in a Gallenkamp muffle furnace size 3 (Thermo Fisher Scientific Inc., Waltham, MA) for 16 $\mathrm{h}$ at $500^{\circ} \mathrm{C}$. Samples were analyzed for NDF and ADF concentrations using the Ankom Fiber Analyzer (Ankom Technology Corp., Macedon, NY) using procedures determined by Van Soest et al. (1991). The samples were analyzed for OM digestibility (Fibertec Systems, Foss, Ballymount, Ireland) using the neutral detergent cellulase in vitro method of Morgan and Stakelum (1987). Samples were analyzed for P concentration using inductively coupled plasma mass spectrometry. Samples were placed in a Gallenkamp muffle furnace for $4 \mathrm{~h}$ at $500^{\circ} \mathrm{C}$. Samples were then diluted with $3 \mathrm{M}$ $\mathrm{HCl}$. The samples were filtered and diluted with deionized water to a concentration of $0.3 \mathrm{M} \mathrm{HCl}$. The samples were then analyzed using an Agilent ICP-MS 7500ce (Agilent Technologies Inc., Santa Clara, CA) with Agilent ICP ChemStation software.

Weekly samples of treatment concentrates were milled through a 1-mm sieve (Cyclotech 1093 sample mill, Foss Electric) in preparation for analysis of ash, $\mathrm{ADF}, \mathrm{NDF}$, and $\mathrm{CP}$ by near-infrared reflectance spectroscopy (Foss-NIR System). Phosphorus concentration in the weekly concentrate samples was determined using the method described above for determining the $\mathrm{P}$ concentration of the grass samples.

\section{Milk Yield and Composition}

Milking took place daily at 0700 and $1500 \mathrm{~h}$, and individual milk yields were recorded during milking 
(Dairymaster). Milk fat, milk protein, milk lactose, milk urea, and milk CN concentrations were determined weekly from 2 morning and 2 afternoon samples collected on Monday p.m., Tuesday a.m., Thursday p.m., and Friday a.m. Milk composition was determined using a Milkoscan 203 (Foss Electric). Solids-corrected milk yield was calculated using the equation of Tyrrell and Reid (1965).

\section{Detailed Milk Composition Analysis}

Once in wk 7 and twice in wk 8, milk samples were collected from 2 successive a.m. and p.m. milkings. Milk samples collected were proportional to the milk yield at that milking for each cow. The milk samples from the 2 milkings from each cow were composited per treatment.

From the composite milk samples, approximately 500 $\mathrm{mL}$ per treatment was used for detailed wet chemistry of $\mathrm{N}$ fractions; namely, total milk protein percentage, NPN, and noncasein N. Total milk protein percentage, NPN, and noncasein $\mathrm{N}$ were established using the Kjeldahl method [methods 20-3 (IDF, 2004b), 20-4 (IDF, 2001), and 29-1 (IDF, 2004a), respectively] using a Tecator Digestor Auto and Kjeltec 8400 distiller (Foss Electric).

A further $1,000 \mathrm{~mL}$ of milk per treatment was skimmed using a Disc Bowl Centrifuge (Armfield Ltd., Ringwood, UK). The milk was heated to $40^{\circ} \mathrm{C}$ in a waterbath and then poured into the bowl section of the centrifuge. After approximately $20 \mathrm{~s}$, the top valve was opened to allow the milk into the separating discs. The skim milk was collected and the cream discarded. The centrifuge was dismantled and all of the components cleaned. Once reassembled, the process was repeated for the milk samples from the other treatments.

The skim milk samples were analyzed for concentrations of $\mathrm{P}$ and $\mathrm{Ca}$. Five grams from each skim milk sample per treatment was diluted with $5 \mathrm{~g}$ of $\mathrm{HNO}_{3}$ (69\%, Trace Select for Trace Analysis, Fluka Analytical, Sigma-Aldrich Ireland Ltd., Arklow, Co. Wicklow, Ireland) and $0.5 \mathrm{~g}$ of $\mathrm{HCl}$ (37\%, Fluka Analytical). Samples were digested at 1,600 W using microwave digestion. Samples were held at $160^{\circ} \mathrm{C}$ for $2 \mathrm{~min}$ and then at $180^{\circ} \mathrm{C}$ for $15 \mathrm{~min}$ and cooled for $30 \mathrm{~min}$. Sample were diluted to $100 \mathrm{~mL}$ with Milli-Q water. One milliliter of the $100-\mathrm{mL}$ digest was diluted to $10 \mathrm{~mL}$ with $\mathrm{HNO}_{3}$ (5\%, Fluka Analytical). Samples were assessed for Ca and $\mathrm{P}$ concentrations using inductively coupled plasma mass spectroscopy with an Agilent ASX 500 series auto-sampler (Agilent Technologies UK Ltd., Stockport, UK). The software used was Mass Hunter software (version A. 01.02 patch 4; Agilent Technologies).

One hundred milliliters of the skim milk per treatment was used for protein composition analysis. Sepa- ration of the milk protein fractions was achieved in reverse-phase mode, using an Agilent Poroshell 300SB C18 column $(2.1 \mathrm{~mm} \times 75 \mathrm{~mm}$; Agilent Technologies UK Ltd.). The HPLC equipment consisted of an Agilent 1200s with quaternary pump and multi-wavelength detector. Gradient elution and peak detection were performed according to Mounsey and O'Kennedy (2009). The skim milk samples and standards were prepared according to Guyomarc'h et al. (2007) and diluted volumetrically. All casein and whey standards were supplied by Sigma-Aldrich.

Three hundred milliliters of skim milk per treatment was frozen using a shell freezing bath (Labconco, Kansas City, MO) and freeze-dried under vacuum using a Labconco Freezone 6. The freeze-dried milk powders were stored at $4^{\circ} \mathrm{C}$. The freeze-dried milk powders were reconstituted to $1.5 \%$ protein by adding distilled water and stirring with a magnetic stir bar in a beaker for 6 h. Individual samples were then divided equally into 8 sub-samples. One sub-sample was set aside to measure heat stability or heat coagulation time (HCT), at an unadjusted $\mathrm{pH}$. The remaining sub-samples were adjusted to $\mathrm{pH} 6.2,6.4,6.6,6.8,7.0,7.2$, and 7.4 by dropwise addition of either $0.5 \mathrm{M} \mathrm{HCl}$ or $0.5 \mathrm{M} \mathrm{NaOH}$. Samples were stored overnight in a refrigerator. The following morning, the samples were readjusted for $\mathrm{pH}$ as necessary. The HCT was determined following the method described by Davies and White (1966). Milk from each sub-sample $(3.4 \mathrm{~g})$ was added to glass test tubes (100 mm long, $13 \mathrm{~mm}$ i.d.). The test tubes were placed in a rocker and immersed in an oil bath containing heated mineral oil at a temperature of $140^{\circ} \mathrm{C}$. The HCT was recorded as the time between immersing the sample in the oil bath and visible clots appearing within the test tubes.

\section{$B W$ and $B C S$}

Body weight and BCS were recorded weekly. Body weight was assessed using an electronic portable weighing scales and the Winweigh software package (Tru-Test Ltd., Auckland, New Zealand). During weighing, BCS was assessed by an experienced trained observer using the method of Edmonson et al. (1989), where 1 is emaciated and 5 is obese, with scaled increments of 0.25 .

\section{Grass DMI Measurement}

Individual cow grass DMI was estimated during wk 5 of the study using the $n$-alkane technique (Mayes et al., 1986) modified by Dillon and Stakelum (1989). Grass DMI and fecal output for each cow were estimated according to the methods described by Kennedy et al. (2011). Fecal samples were analyzed for N 
concentration using a Leco N Analyzer (Leco FP-528; Leco Corp.). Fecal samples were also analyzed for P concentration. A portion of the sample was weighed and placed into a Kjeldahl Digestion Flask (Labconco) with $\mathrm{H}_{2} \mathrm{SO}_{4}$ and $\mathrm{H}_{2} \mathrm{O}_{2}$. The sample was then digested in a heating block until clear. The sample was diluted to an exact volume and filtered. Total $\mathrm{P}$ concentration was then determined after the addition of ammonium molybdate by measuring the intensity of the blue compound produced by the reduction of phosphomolybdic acid within a Hach spectrophotometer (Hach Company, Loveland, CO). Fecal N and P excretion was calculated using the estimated fecal output and the analyzed fecal $\mathrm{N}$ and $\mathrm{P}$ concentrations.

\section{Urine Samples}

During the grass DMI collection period, urine samples were collected on 2 consecutive mornings before the a.m. milking. Urine was collected in the paddocks before cows were brought in for milking, in the holding yard, in the milking parlor, and during concentrate feeding. The samples were initially collected in 4-L buckets and were then transferred to $750-\mathrm{mL}$ collection bottles. Urine samples were frozen in preparation for analysis of $\mathrm{P}$ concentration. Inorganic phosphate was analyzed in the urine samples. Ammonium molybdate was added to the samples to form ammonium phosphomolybdate. The concentration of phosphomolybdate formed is directly proportional to the inorganic phosphate concentration within the urine sample. A Roche Integra chemical analyzer (Roche Diagnostics Ltd., Burgess Hill, UK) was used for analysis of phosphomolybdate, which was determined by measuring the increase in absorbance at $340 \mathrm{~nm}$. Urine creatinine concentration was assessed using a kit (A11A01933, Horiba ABX, Montpellier, France) and analyzed on an ABX Pentra 400 autoanalyzer (ABX Mira, CEDEX 4, France). Urine volume was calculated using creatinine as a marker assuming a creatinine excretion of $29 \mathrm{mg} /$ $\mathrm{kg}$ of BW per day (Valadares et al., 1999). Urine P excretion was calculated using the estimated urine volume and the analyzed $\mathrm{P}$ concentration. Urinary $\mathrm{N}$ (UN) excretion was determined by subtracting the $\mathrm{N}$ excreted in the milk and feces from the total $\mathrm{N}$ intake (van Vuuren et al., 1993).

\section{Blood Samples}

Blood samples were collected from each cow via coccygeal venipuncture on 3 occasions before the experimental period, in wk 3 of the experimental period, and in wk 8 of the experimental period. Blood samples were collected immediately after the morning milking. Two blood samples from each animal were collected into 2 Vacutainers (BD, Dun Laoghaire, Ireland), one with no additive, the other containing lithium heparin as an anticoagulant. Samples collected into the lithiumheparinized Vacutainers were immediately centrifuged at $3,000 \times g\left(4^{\circ} \mathrm{C}\right)$ for $10 \mathrm{~min}$. The plasma was decanted and frozen at $-20^{\circ} \mathrm{C}$ before analysis. Samples were analyzed for BHBA, NEFA, total protein, BUN, glucose, and albumin concentrations. Analyses were carried out using appropriate kits (glucose, total protein, and urea N: ABX Mira; NEFA: Wako Chemicals GmbH, Neuss, Germany; BHBA: Randox Laboratories Ltd., Crumlin, UK; albumin: A11A01664, Horiba ABX) on an ABX Pentra 400 autoanalyzer (ABX Mira). Samples collected into the Vacutainer with no additive were refrigerated at $4^{\circ} \mathrm{C}$ for $24 \mathrm{~h}$, before being centrifuged at $3,000 \times g\left(4^{\circ} \mathrm{C}\right)$ for $15 \mathrm{~min}$. The serum was decanted and frozen. These samples were transferred frozen to the Agri-Food and Biosciences Institute (Belfast, UK) for analysis of $\mathrm{P}$ concentration using an Olympus Clinical Chemical Analyzer AU640 (Olympus America Inc., Center Valley, PA).

\section{Statistical Analysis}

All statistical analysis was carried out using the MIXED procedure of SAS 9.1.3 (SAS Institute, 2005). The model for milk yield, SCM yield, milk fat concentration, milk protein concentration, milk solids yield, CN concentration, CN number, and MUN concentration included treatment, week, treatment $\times$ week interaction, concentrate intake, and the respective covariate (pre-experimental measurement). Week of experiment was included as the repeated effect. The model for the blood metabolites and $\mathrm{P}$ concentration included treatment, sample period (wk 3 or wk 8 ), treatment $\times$ sample period interaction, concentrate intake, and the respective covariate (pre-experimental measurement). Sample period was included as the repeated effect. The model to analyze BW change and BCS change did not include a repeated statement, and no interaction of week and treatment was included in the model. In all cases, cow was treated as a random effect and the covariance structure with the lowest Akaike information criterion was retained in the final model (compound symmetry).

Heat coagulation times were analyzed by using the PROC MIXED statement of SAS 9.1.3 (SAS Institute, 2005), with treatment, $\mathrm{pH}$, and the interaction of treatment and $\mathrm{pH}$ included in the model. The repeated measure was $\mathrm{pH}$ and the covariance structure used was compound symmetry.

Data for grass DMI, concentrate DMI, total DMI, $\mathrm{CP}$ intake, NDF intake, energy intake, milk $\mathrm{N}$ fractions, 
REID ET AL.

Table 1. Chemical composition of the grass for grazing by lactating dairy cows during the 8-wk experiment

\begin{tabular}{|c|c|c|c|c|c|c|}
\hline \multirow[b]{2}{*}{ Item } & \multicolumn{4}{|c|}{ Treatment $^{1}$} & \multirow[b]{2}{*}{ SEM } & \multirow[b]{2}{*}{ Significance } \\
\hline & $\mathrm{HPrHP}$ & MPrHP & LPrHP & LPrLP & & \\
\hline $\mathrm{DM}(\mathrm{g} / \mathrm{kg})$ & 185 & 187 & 185 & 183 & 4.1 & NS \\
\hline Ash $(\mathrm{g} / \mathrm{kg}$ of $\mathrm{DM})$ & 84 & 82 & 79 & 82 & 1.2 & NS \\
\hline $\mathrm{CP}(\mathrm{g} / \mathrm{kg}$ of $\mathrm{DM})$ & 275 & 264 & 265 & 266 & 5.7 & NS \\
\hline $\mathrm{NDF}(\mathrm{g} / \mathrm{kg}$ of $\mathrm{DM})$ & 329 & 331 & 329 & 334 & 2.5 & NS \\
\hline $\mathrm{ADF}(\mathrm{g} / \mathrm{kg}$ of $\mathrm{DM})$ & 226 & 224 & 226 & 227 & 6.9 & NS \\
\hline $\mathrm{OM}$ digestibility $^{2}(\mathrm{~g} / \mathrm{kg}$ of $\mathrm{DM})$ & 862 & 866 & 867 & 864 & 1.35 & NS \\
\hline $\mathrm{P}(\mathrm{g} / \mathrm{kg}$ of $\mathrm{DM})$ & 2.70 & 2.66 & 2.70 & 2.70 & 0.05 & NS \\
\hline
\end{tabular}

milk protein composition, fecal $\mathrm{N}$ and $\mathrm{P}$ concentrations, urine $\mathrm{N}$ and $\mathrm{P}$ concentrations, grass chemical composition, and concentrate chemical composition were analyzed using the PROC MIXED statement of SAS 9.1.3 (SAS Institute, 2005). No repeated statement, covariate, or covariance structure was used in the model.

In all cases where the PROC MIXED statement of SAS 9.1.3 (SAS Institute, 2005) was used, statistically significant differences between least squares means were tested using the Tukey test for pairwise comparison of treatment means.

Correlations between dietary CP concentration and total protein concentration of the composite milk samples, dietary CP and NPN concentrations of the composite milk samples and between MUN and HCT at $\mathrm{pH}$ 7.4 were analyzed using the PROC REG statement of SAS 9.1.3 (SAS Institute, 2005). The model included milk total protein, NPN, and HCT as the $\mathrm{Y}$ variables, respectively, and dietary $\mathrm{CP}$ concentration and MUN concentration as the $\mathrm{X}$ variables, respectively.

\section{RESULTS}

\section{Grazing Management}

Treatment HPrHP $(1,529 \mathrm{~kg}$ of DM/ha \pm 36$)$ had a lower PGHM than LPrLP $(1,672 \mathrm{~kg}$ of DM/ha \pm 36$)(P$ $<0.05)$. The PGHM of MPrHP was $1,571 \mathrm{~kg}$ of DM/ ha \pm 36 and $\mathrm{LPrHP}$ was $1,580 \mathrm{~kg}$ of $\mathrm{DM} / \mathrm{ha} \pm 36$, and these were not significantly different from the other 2 treatments. The equivalent PGHM at ground level was $3,029,3,071,3,080$, and $3,172 \mathrm{~kg}$ of $\mathrm{DM} / \mathrm{ha} \pm 36$ for the HPrHP, MPrHP, LPrHP, and LPrHP treatments, respectively. Mean pregrazing sward heights during the study were 9.6, 9.8, 9.6, and $10.1 \pm 1.83 \mathrm{~cm}$ for the HPrHP, MPrHP, LPrHP, and LPrLP treatments, respectively. The mean postgrazing sward heights were $3.7,3.7,3.8$, and $3.9 \mathrm{~cm} \pm 0.05$, respectively. We detected no significant differences among treatments in pre- or postgrazing sward heights. The chemical composition of the grass throughout the study is shown in Table 1 and was similar among treatments. The chemical composition of the concentrates offered throughout the experiment is presented in Table 2. As intended, the concentrations of $\mathrm{CP}$ and $\mathrm{P}$ differed among the concentrates. The $\mathrm{CP}$ concentrations were similar to that formulated, whereas the $\mathrm{P}$ concentration of the HPrHP, MPrHP, and LPrHP concentrates was lower than formulated but still greatly in excess of the $\mathrm{P}$ concentration of LPrLP, as intended.

\section{Milk Yield and Composition}

Milk yield and composition are presented in Table 3 . Milk yield, milk fat and protein concentrations, milk solids yield, and SCM yield were not significantly affected by treatment and we found no treatment $\times$ time interaction. Milk urea $\mathrm{N}$ was significantly affected by treatment and we observed a treatment $\times$ time interaction $(P<0.001 ;$ Figure 1$)$. During the first $7 \mathrm{wk}$ of the 8-wk study, the MUN concentration in HPrHP was significantly greater than that of LPrHP and LPrLP (Figure 1). During wk 1, 2, 5, and 7, the MPrHP treatment had higher MUN concentrations than the LPrHP and LPrLP treatments. Casein concentration was not affected by treatment; however, CN number, which is the percentage of $\mathrm{CN}$ in total milk protein, was lower in the MPrHP, LPrHP, and LPrLP treatments compared with HPrHP $(P<0.05$; Table 3$)$. We detected no significant effect of treatment $\times$ time interaction on $\mathrm{CN}$ concentration or $\mathrm{CN}$ number.

\section{Detailed Milk Composition and Protein Composition}

Although treatment did not significantly affect composite milk sample $\mathrm{N}$ fractions (Table 4), we detected a significant positive correlation between dietary $\mathrm{CP}$ and composite milk total protein concentration (Figure 
Table 2. Chemical composition of the concentrates offered to grazing lactating dairy cows during the 8-wk experiment

\begin{tabular}{lcccccc}
\hline & \multicolumn{9}{c}{ Treatment $^{1}$} & & \\
\cline { 2 - 5 } Item & HPrHP & MPrHP & LPrHP & LPrLP & SEM & Significance \\
\hline Ash (g/kg of DM) & $70^{\mathrm{a}}$ & $70^{\mathrm{a}}$ & $40^{\mathrm{b}}$ & $21^{\mathrm{c}}$ & 1.5 & $* * *$ \\
CP (g/kg of DM) & $277^{\mathrm{a}}$ & $198^{\mathrm{b}}$ & $93^{\mathrm{c}}$ & $86^{\mathrm{c}}$ & 1.7 & $* * *$ \\
NDF (g/kg of DM) & $207^{\mathrm{ab}}$ & $240^{\mathrm{a}}$ & $190^{\mathrm{b}}$ & $198^{\mathrm{b}}$ & 4.7 & $* *$ \\
ADF (g/kg of DM) & $84^{\mathrm{a}}$ & $108^{\mathrm{b}}$ & $123^{\mathrm{c}}$ & $127^{\mathrm{c}}$ & 0.9 & $* * *$ \\
P (g/kg of DM) & $6.09^{\mathrm{a}}$ & $4.19^{\mathrm{b}}$ & $4.52^{\mathrm{ab}}$ & $0.52^{\mathrm{c}}$ & 0.221 & $* * *$ \\
\hline
\end{tabular}

${ }^{\mathrm{a}-\mathrm{c}}$ Means within a row with different superscripts differ significantly.

${ }^{1}$ Treatments: HPrHP $=$ high CP, high P; MPrHP = medium CP, high P; LPrHP = low CP, high P; LPrLP $=$ low $\mathrm{CP}$, low $\mathrm{P}$.

${ }^{* *} P<0.01,{ }^{* * *} P<0.001$.

2a). We also found a significant positive relationship between dietary $\mathrm{CP}$ and composite milk NPN concentration (Figure 2b).

The concentrations of $\mathrm{P}$ and $\mathrm{Ca}$ in the composite milk samples did not differ among treatments. Milk $\mathrm{P}$ concentration for the HPrHP, MPrHP, LPrHP, and LPrLP treatments was $0.81,0.90,0.97$, and $0.94 \pm$ $0.073 \mathrm{~g} / \mathrm{kg}$, respectively. Milk Ca concentration for the HPrHP, MPrHP, LPrHP, and LPrLP were 0.97, 1.12, 1.22 , and $1.16 \pm 0.082 \mathrm{~g} / \mathrm{kg}$, respectively.

The protein composition of the composite milk samples is presented in Table 5 . We detected an effect of treatment on the concentration of $\alpha_{\mathrm{S} 1}-\mathrm{CN}$. The LPrHP and LPrLP treatments had a greater concentration of $\alpha_{S 1}$-CN compared with HPrHP. Treatment MPrHP was intermediate and did not differ compared with the oth- er treatments. We also detected an effect of treatment on the concentration of $\beta$-LG. Treatments MPrHP and LPrHP had a greater concentration of $\beta$-LG than treatment HPrHP; treatment LPrLP was intermediate and did not differ compared with the other treatments.

\section{HCT}

The HCT for the treatments across a $\mathrm{pH}$ range from 6.2 to 7.4 are presented in Figure 3. A significant interaction existed between treatment and $\mathrm{pH}(P<$ 0.001). At pH 6.8, the HCT of MPrHP was significantly greater than that of HPrHP. Treatments LPrHP and LPrLP were not significantly different from HPrHP or MPrHP. We found a positive correlation between MUN concentration and HCT at $\mathrm{pH} 7.4(P<0.05$; Figure

Table 3. The effect of offering supplementary concentrates differing in $\mathrm{CP}$ and phosphorus concentration to early-lactation grazing dairy cows in spring on milk yield and composition, BW, BCS, and DMI

\begin{tabular}{|c|c|c|c|c|c|c|}
\hline \multirow[b]{2}{*}{ Item } & \multicolumn{4}{|c|}{ Treatment $^{1}$} & \multirow[b]{2}{*}{ SEM } & \multirow[b]{2}{*}{ Significance } \\
\hline & $\mathrm{HPrHP}$ & MPrHP & LPrHP & LPrLP & & \\
\hline Milk yield (kg/d) & 27.4 & 26.9 & 26.1 & 27.1 & 0.42 & NS \\
\hline Milk fat $(\mathrm{g} / \mathrm{kg})$ & 45.1 & 45.5 & 44.4 & 45.7 & 0.50 & NS \\
\hline Milk protein $(\mathrm{g} / \mathrm{kg})$ & 34.1 & 33.6 & 33.7 & 33.7 & 0.24 & NS \\
\hline Milk solids yield $(\mathrm{kg} / \mathrm{d})$ & 2.1 & 2.1 & 2.0 & 2.1 & 0.03 & NS \\
\hline BW change (kg) & 39 & 23 & 12 & 22 & 3.3 & NS \\
\hline BCS change & -0.05 & -0.10 & -0.13 & -0.05 & 0.036 & NS \\
\hline Grass DMI (kg of DM/cow per day) & 12.3 & 13.2 & 14.1 & 13.6 & 0.26 & $\dagger$ \\
\hline Concentrate DMI ( $\mathrm{kg}$ of DM/cow per day) & $3.97^{\mathrm{a}}$ & $4.01^{\mathrm{a}}$ & $3.79^{\mathrm{ab}}$ & $3.66^{\mathrm{b}}$ & 0.040 & $* *$ \\
\hline Total DMI (kg of DM/cow per day) & 16.1 & 17.1 & 18.0 & 17.5 & 0.26 & $\dagger$ \\
\hline $\mathrm{CP}$ intake (kg of DM/cow per day) & 4.54 & 4.40 & 4.25 & 4.12 & 0.139 & NS \\
\hline NDF intake (kg of DM/cow per day) & 4.86 & 5.30 & 5.40 & 5.28 & 0.168 & NS \\
\hline
\end{tabular}

\footnotetext{
${ }^{\mathrm{a}, \mathrm{b}}$ Means within a row with different superscripts differ significantly.

${ }^{1}$ Treatments: HPrHP = high CP, high P; MPrHP = medium CP, high P; LPrHP = low CP, high P; LPrLP = low CP, low P.

${ }^{2}$ Casein number $=($ casein $\% /$ milk protein $\%) \times 100$.

${ }^{3} \mathrm{UFL}=$ unité fourragère lait; $1 \mathrm{UFL}=1.7 \mathrm{Mcal}$ (INRA, 1989).

$\dagger=P<0.10,{ }^{*} P<0.05,{ }^{* *} P<0.01$.
} 


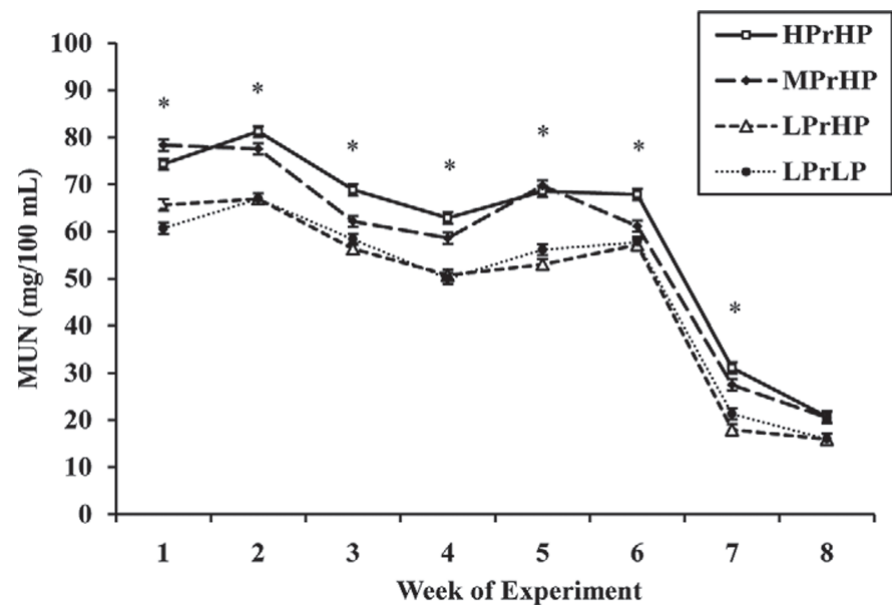

Figure 1. The effect of offering supplementary concentrates differing in $\mathrm{CP}$ and phosphorus concentration to early-lactation grazing dairy cows in spring on MUN concentration. Treatments: HPrHP = high $\mathrm{CP}$, high $\mathrm{P}$; MPrHP = medium $\mathrm{CP}$, high $\mathrm{P}$; $\mathrm{LPrHP}=$ low $\mathrm{CP}$, high $\mathrm{P}$; LPrLP $=$ low $\mathrm{CP}$, low P. *Significant differences between treatments in this observation week $(P<0.05)$.

4). At the natural unadjusted $\mathrm{pH}, \mathrm{MPrHP}(7.8 \pm 0.60$ min) had a greater HCT than HPrHP $(3.8 \pm 0.60 \mathrm{~min})$, $\mathrm{LPrHP}(4.3 \pm 0.60 \mathrm{~min})$, and $\operatorname{LPrLP}(5.3 \pm 0.60 \mathrm{~min})$ $(P<0.001)$.

\section{$B W, B C S$, and DMI}

We observed no significant effect of treatment on BW change or BCS change (Table 3). Grass DMI, concentrate DMI, and total DMI are presented in Table 3. There was an effect of treatment on concentrate intake $(P<0.01)$. The LPrLP treatment had a significantly lower concentrate intake than the HPrHP and MPrHP treatments. Grass DMI and total DMI tended to be higher in HPrHP than in LPrHP $(P<0.1)$. The grass DMI and total DMI of MPrHP and LPrLP were in-
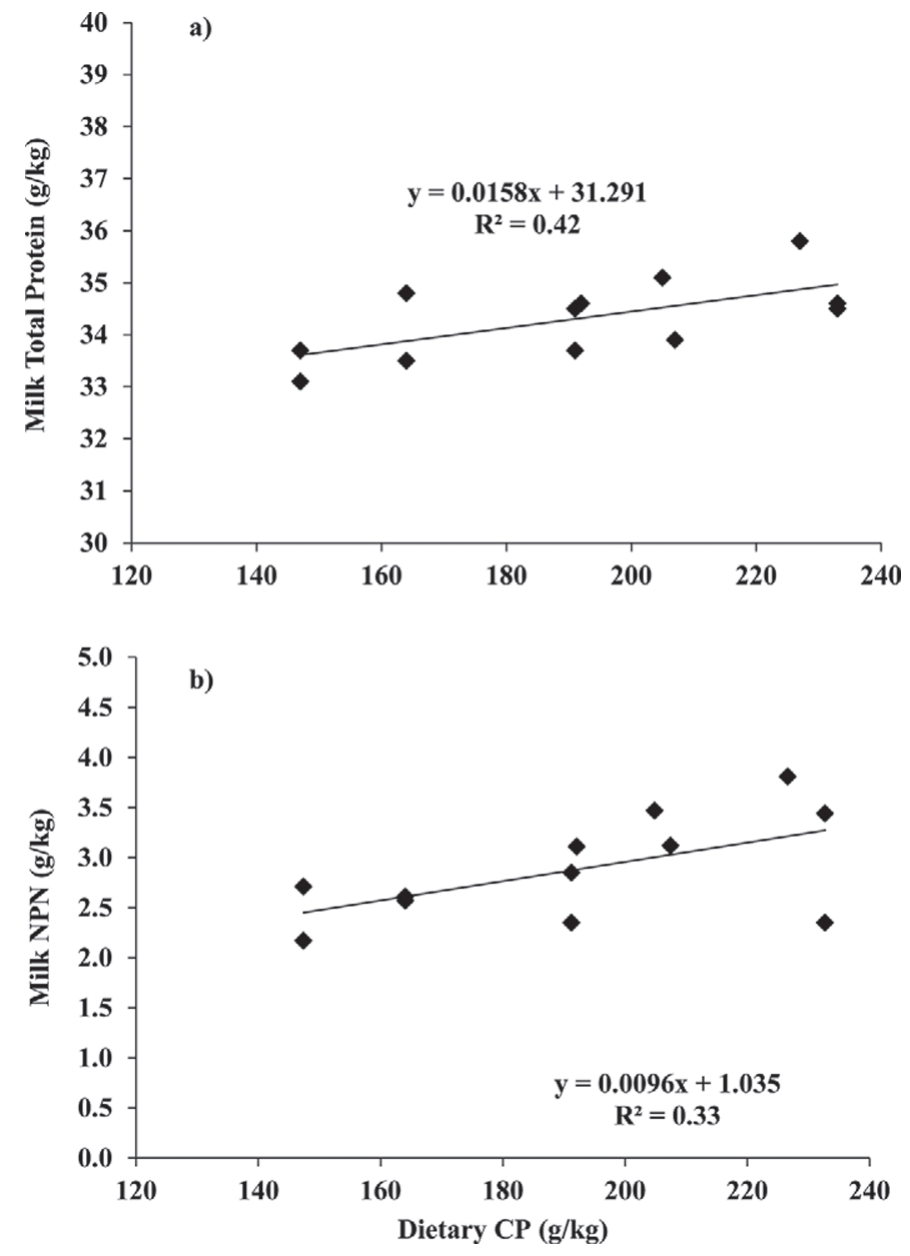

Figure 2. The relationship between dietary $\mathrm{CP}$ concentration and (a) milk total protein concentration, and (b) milk NPN concentration in early-lactation grazing dairy cows in spring offered supplementary concentrates differing in $\mathrm{CP}$ and phosphorus concentration.

Table 4. The effect of offering supplementary concentrates differing in CP and phosphorus concentration to early-lactation grazing dairy cows in spring on milk nitrogen fractions

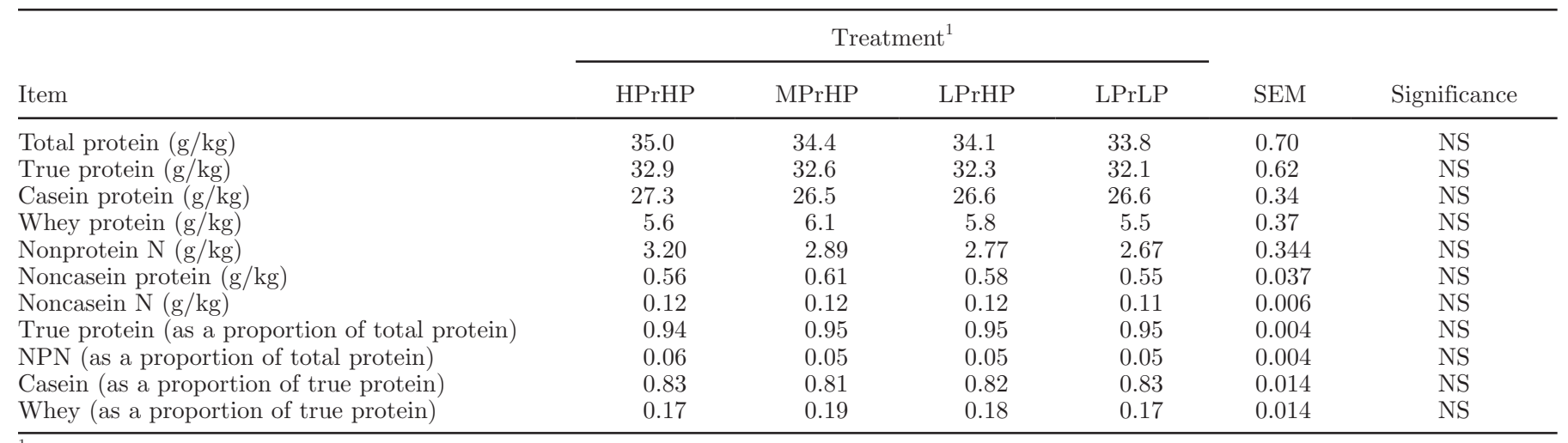

${ }^{1}$ Treatments: HPrHP $=$ high CP, high P; MPrHP = medium CP, high P; LPrHP = low CP, high P; LPrLP = low CP, low P. 


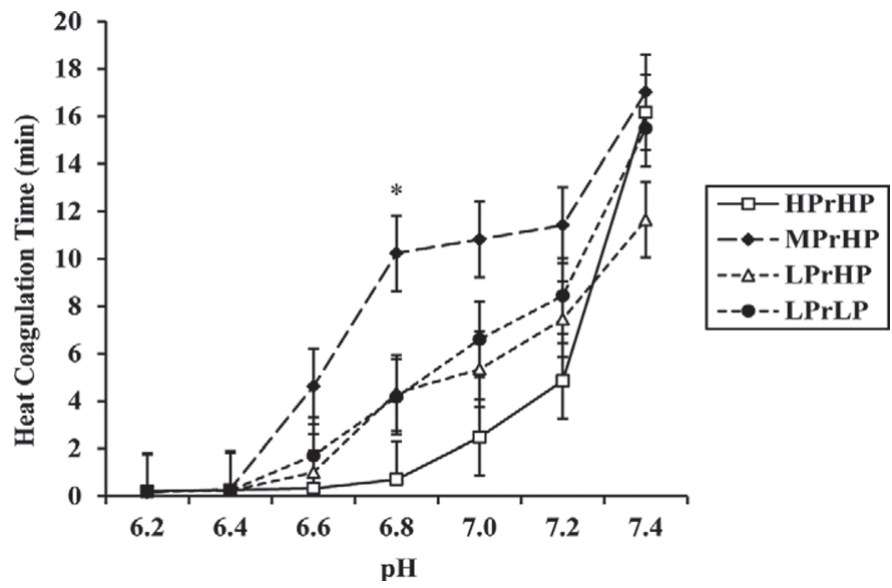

Figure 3. The effect of offering supplementary concentrates differing in $\mathrm{CP}$ and phosphorus concentration to early-lactation grazing dairy cows in spring on heat coagulation time of milk. Treatments: $\mathrm{HPrHP}=\operatorname{high} \mathrm{CP}$, high $\mathrm{P} ; \mathrm{MPrHP}=$ medium $\mathrm{CP}$, high $\mathrm{P} ; \mathrm{LPrHP}=$ low $\mathrm{CP}$, high P; LPrLP = low CP, low P. *Significant differences between treatments in this observation week $(P<0.05)$. The error bars represent SEM for each pH LSM.

termediate and did not differ from those of any other treatment. Treatment did not affect intake of CP, NDF, or energy.

\section{Urine and Feces Analysis}

Nitrogen and $\mathrm{P}$ intake and excretion data are presented in Table 6. As intended, differences were detected among treatments in concentrate $\mathrm{N}$ intake $(P<$ 0.001), but we found no significant effect of treatment on grass $\mathrm{N}$ intake or total $\mathrm{N}$ intake. Fecal $\mathrm{N}$ and urine $\mathrm{N}$ excretion did not differ significantly among treatments. Treatment did not affect total $\mathrm{N}$ excretion or the proportion of $\mathrm{N}$ intake excreted $(P>0.05)$.

We found no significant effect of treatment on grass $\mathrm{P}$ intake but did detect differences among treatments in concentrate $\mathrm{P}$ intake $(P<0.001)$. Treatment LPrLP

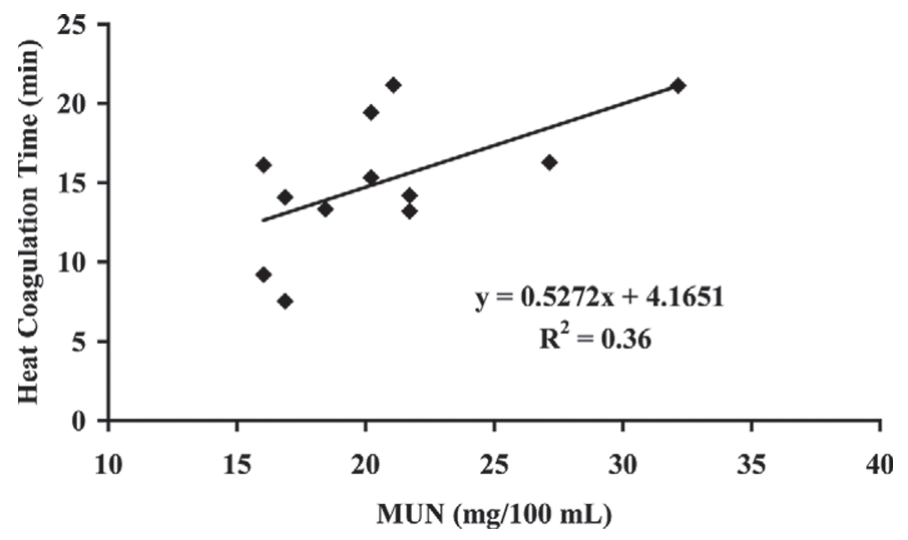

Figure 4. The relationship at $\mathrm{pH} 7.4$ between MUN concentration and milk heat coagulation time in early-lactation grazing dairy cows in spring offered supplementary concentrates differing in $\mathrm{CP}$ and phosphorus concentration.

had a lower total $\mathrm{P}$ intake than all other treatments $(P<0.001)$. Fecal $\mathrm{P}$ excretion was greater in HPrHP, MPrHP, and LPrHP compared with LPrLP $(P<$ 0.001). We detected no differences in urinary $\mathrm{P}$ excretion among treatments. Total $\mathrm{P}$ excretion in feces and urine was greater in HPrHP, MPrHP, and LPrHP compared with LPrLP $(P<0.001)$. Treatment did not affect $\mathrm{P}$ excretion in feces and urine as a proportion of total $\mathrm{P}$ intake.

\section{Blood Metabolites}

We detected no significant difference in the concentration of glucose (mean $\pm \mathrm{SEM} ; 3.2 \mathrm{mmol} / \mathrm{L} \pm 0.07$ ), NEFA $(0.31 \mathrm{mmol} / \mathrm{L} \pm 0.027)$, BHBA $(0.30 \mathrm{mmol} / \mathrm{L}$ $\pm 0.013)$, total protein $(67.3 \mathrm{~g} / \mathrm{L} \pm 1.53)$, and albumin $(26.8 \mathrm{~g} / \mathrm{L} \pm 0.70)$ among treatments. We detected a significant interaction between treatment and time on BUN concentration (Figure 5): in wk 3, BUN concentration in HPrHP was significantly greater than that in

Table 5. The effect of offering supplementary concentrates differing in CP and phosphorus concentration to early-lactation grazing dairy cows in spring on milk protein composition

\begin{tabular}{|c|c|c|c|c|c|c|}
\hline \multirow[b]{2}{*}{ Milk protein } & \multicolumn{4}{|c|}{ Treatment $^{1}$} & \multirow[b]{2}{*}{ SEM } & \multirow[b]{2}{*}{ Significance } \\
\hline & HPrHP & MPrHP & LPrHP & LPrLP & & \\
\hline$\alpha_{\mathrm{S} 1}$-Casein $(\mathrm{g} / \mathrm{L})$ & $11.31^{\mathrm{a}}$ & $11.69^{\mathrm{ab}}$ & $12.63^{\mathrm{b}}$ & $12.41^{\mathrm{b}}$ & 0.105 & $*$ \\
\hline$\alpha_{\mathrm{S}^{2}}$-Casein $(\mathrm{g} / \mathrm{L})$ & 2.42 & 2.26 & 2.36 & 2.28 & 0.065 & NS \\
\hline$\beta$-Casein $(\mathrm{g} / \mathrm{L})$ & 7.25 & 8.67 & 8.44 & 8.26 & 0.312 & NS \\
\hline$\kappa$-Casein $(\mathrm{g} / \mathrm{L})$ & 2.86 & 3.28 & 3.12 & 3.05 & 0.099 & NS \\
\hline$\beta$-Lactoglobulin (g/L) & $3.64^{\mathrm{a}}$ & $4.21^{\mathrm{b}}$ & $4.20^{\mathrm{b}}$ & $4.09^{\mathrm{ab}}$ & 0.100 & $*$ \\
\hline$\alpha$-Lactalbumin $(\mathrm{g} / \mathrm{L})$ & 0.81 & 0.85 & 0.83 & 0.83 & 0.009 & NS \\
\hline
\end{tabular}




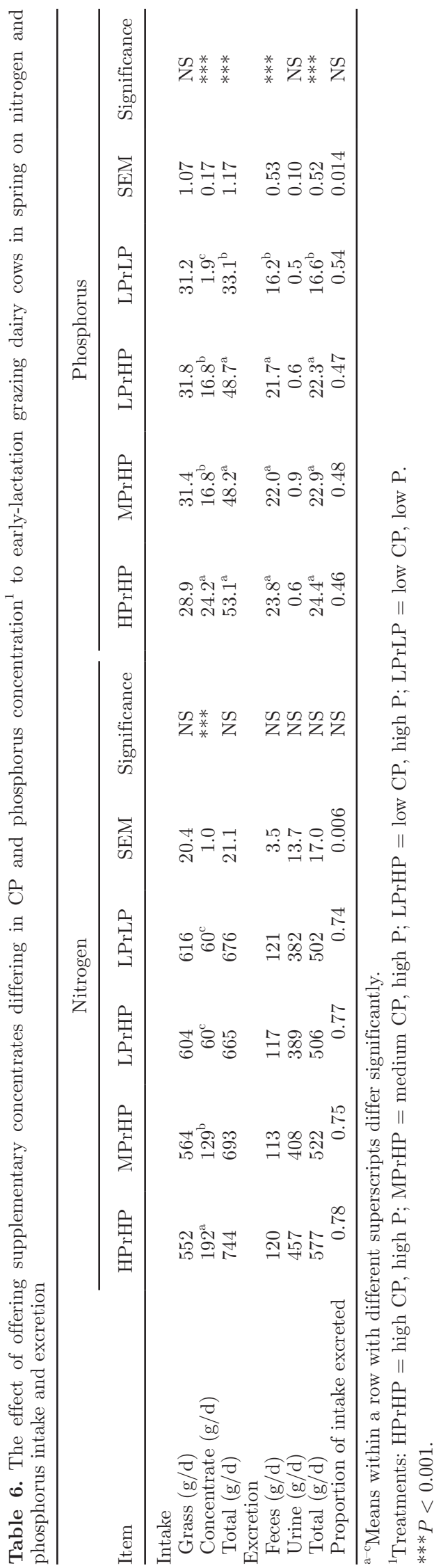

LPrHP and LPrLP. We detected no difference between MPrHP and any of the other treatments. In wk 8, BUN concentrations in all treatments were significantly greater than that in LPrLP. We also found a significant interaction between treatment and time on blood $\mathrm{P}$ concentration $(P<0.05$; Figure 6$)$. In the middle of the experiment (wk 3), there were no differences among the treatments, but by the end of the experiment (wk 8), the treatment groups HPrHP, MPrHP, and LPrHP all had a significantly higher blood $\mathrm{P}$ concentrations than the LPrLP treatment.

\section{DISCUSSION}

The objective of this study was to investigate the effects on milk yield, composition, and heat stability, and animal $\mathrm{N}$ and $\mathrm{P}$ status, of offering concentrate supplements that differed in $\mathrm{CP}$ and $\mathrm{P}$ concentration to grazing dairy cows in early lactation. To achieve differences in dietary $\mathrm{CP}$ and $\mathrm{P}$, different supplementary feeds containing different concentrations of $\mathrm{CP}$ and $\mathrm{P}$ were offered to dairy cows grazing similar grass.

The sward parameters in this study indicate high quality grass in the spring period, as outlined in other Irish grazing studies (Kennedy et al., 2008; Curran et al., 2010). In all treatments, similar pregrazing and postgrazing sward heights were maintained, and grass chemical composition was also similar. This indicated that animals in the different treatments grazed and ingested grass of similar quality.

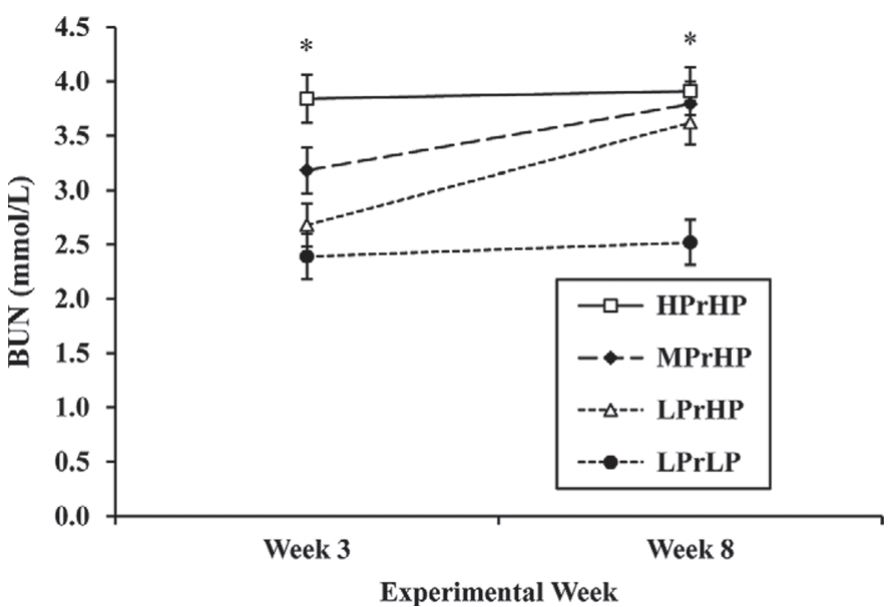

Figure 5. The effect of offering supplementary concentrates differing in $\mathrm{CP}$ and phosphorus concentration to early-lactation grazing dairy cows in spring on BUN concentration. Treatments: HPrHP = high $\mathrm{CP}$, high $\mathrm{P}$; MPrHP = medium $\mathrm{CP}$, high $\mathrm{P}$; LPrHP = low $\mathrm{CP}$, high P; LPrLP $=$ low CP, low P. *Significant differences between treatments in this observation week $(P<0.05)$. The error bars represent SEM for each week's LSM. 


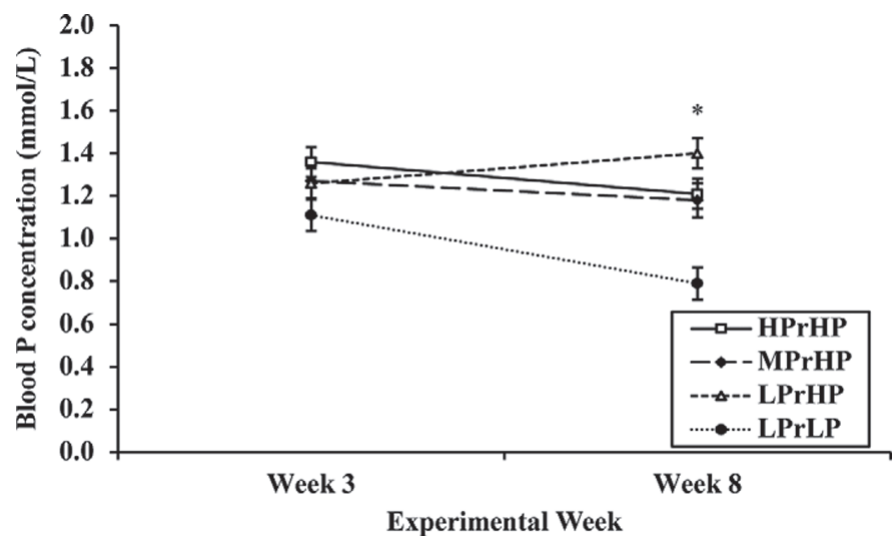

Figure 6. The effect of offering supplementary concentrates differing in $\mathrm{CP}$ and phosphorus concentration to early lactation grazing dairy cows in spring on blood phosphorus concentration. Treatments: $\mathrm{HPrHP}=$ high $\mathrm{CP}$, high $\mathrm{P} ; \mathrm{MPrHP}=$ medium $\mathrm{CP}$, high $\mathrm{P} ; \mathrm{LPrHP}=$ low $\mathrm{CP}$, high P; LPrLP = low CP, low P. *Significant differences between treatments in this observation week $(P<0.05)$. The error bars represent SEM for each week's LSM.

Blood parameters such as glucose, NEFA, BHBA, total protein, and albumin concentrations can be used as indicators of nutritional stress (LeBlanc, 2010). During wk 3 and 8 of the present study, concentrations of these blood parameters were similar among treatments and were within normal ranges (Mee and Nolan, 1994).

\section{Nitrogen}

Dry matter intake is a factor limiting milk production in early lactation (Bargo et al., 2003). Cows in the different treatments in this study were offered the same allocation of grass and concentrate. Total DMI tended to be different between the HPrHP and LPrHP treatments; however, treatment did not affect milk yield or milk solids yield. This agrees with other studies in which different dietary CP concentrations offered to cows had no effect on milk yield or milk solids yield (Leonardi et al., 2003; Olmos Colmenero and Broderick, 2006). Milk protein concentration was also not affected by treatment in the present study. Broderick (2003) found that when dietary CP concentrations of 15.1 to $16.7 \%$ DM were offered to cows, milk protein concentration increased with increasing dietary $\mathrm{CP}$. When dietary $\mathrm{CP}$ concentrations increased to $18.4 \% \mathrm{DM}$, however, no further increases in milk protein concentration were detected. Even in the LPrLP and LPrHP treatments in the present study, dietary CP was $22.9 \%$ DM due to the high $\mathrm{CP}$ concentration of the grass grazed by cows. The results of the present study therefore agree with Broderick (2003) that milk protein concentration is unaffected by dietary $\mathrm{CP}$ increases above $17.0 \% \mathrm{DM}$ dietary CP.
The relationship between BUN, UN, and MUN is well established (Spek et al., 2012). Blood urea N diffuses from the blood to other fluid pools in the body, such as milk (MUN) or urine (UN), in order for the urea to be excreted (Spek et al., 2012). An increase in BUN therefore leads to an increase in MUN and UN concentrations (Kauffman and St-Pierre, 2001; Burgos et al., 2007). For a lactating dairy cow, the CP requirement ranges from 14.0 to $18.0 \%$ DM CP depending on DMI, BW, milk production, and the efficiency with which protein is utilized by the animal (NRC, 2001). In the present study, dietary $\mathrm{CP}$ concentrations ranged from 22.9 to $28.2 \%$ DM due to the high CP concentration in grass. In all treatments, therefore, dietary $\mathrm{CP}$ exceeded requirements although differences existed among treatments in regard to the degree of excess. The HPrHP treatment had the highest CP concentration and therefore the greatest dietary $\mathrm{CP}$ excess and correspondingly highest concentrations of BUN and MUN. The low CP treatments (LPrHP, LPrLP) had the lowest $\mathrm{CP}$ concentrations and hence the lowest dietary CP excess and lowest concentrations of BUN and MUN. This agrees with previous research by Borucki Castro et al. (2008), Law et al. (2009), and Spek et al. (2012). In the present study, concentrations of BUN, MUN, and UN were greater than those reported in the afore-mentioned studies because of the higher levels of dietary CP in the present study. Mulligan et al. (2004) recorded MUN concentrations of approximately 15 to $20 \mathrm{mg} / 100 \mathrm{~mL}$ in grass-fed dairy cows, which is lower than those recorded in the present study. Dietary CP concentrations were, however, lower $(20.0 \% \mathrm{CP} / \mathrm{kg}$ of $\mathrm{DM}$ ) in that study than in the present study. Concentrations of MUN for all treatments decreased in the final 2 wk of the study. This was associated with an overall decrease in grass $\mathrm{CP}$ concentrations, which declined from an average of $26.0 \% \mathrm{CP}$ DM in the first 6 wk to $21.0 \%$ CP DM in the last 2 wk of the study.

Total daily fecal $\mathrm{N}$ excretion was not significantly affected by treatment, which was not unexpected because fecal $\mathrm{N}$ excretion is known to be poorly related to dietary $\mathrm{N}$ intake (Whelan et al., 2012). These results are consistent with the results of other research in lactating dairy cows (Mulligan et al., 2004; Steinshamn et al., 2006). Urine is the primary route for urea excretion (Spek et al., 2013) and other studies have shown that UN excretion is positively associated with dietary $\mathrm{N}$ concentration (Olmos Colmenero and Broderick, 2006). In the present study, supplementing with a low $\mathrm{CP}$ concentrate led to a reduction in UN; however, significance was not attained. A reduction in UN excretion is positive from an environmental perspective.

With increases in dietary $\mathrm{CP}$ concentration, there was a significant increase in the concentration of NPN 
in the composite milk samples, agreeing with the studies of Bargo et al. (2002) and Broderick (2003). Increased milk NPN concentration is undesirable because NPN has no economic value to a milk processor, particularly if the milk is being used for cheese production (DePeters and Ferguson, 1992). Therefore, supplementing with a high CP concentrate, such as in the HPrHP treatment in the present study, has little benefit from the milk processor's perspective.

The 6 major proteins found in bovine milk are $\alpha_{S_{1}-}$ $\mathrm{CN}, \alpha_{\mathrm{S} 2^{-}} \mathrm{CN}, \beta-\mathrm{CN}, \kappa-\mathrm{CN}$, and the whey proteins $\alpha-\mathrm{LA}$ and $\beta-\mathrm{L}$. To a large extent, the concentrations of these proteins in milk determine the nutritional value and technological properties of milk (Dalgleish, 1993). The concentrations of the 6 major proteins in all of the treatments were within the range specified by Farrell et al. (2004). There was, however, an effect of treatment on the concentration of some of these proteins. The $\alpha_{\mathrm{S} 1}-\mathrm{CN}$ concentration was greater in the LPrHP and LPrLP treatments than in the HPrHP. $\alpha_{\mathrm{S}^{-}}$Casein is the principal component of the $\mathrm{CN}$ micelles, which are dispersed as a colloid in milk (Fox and McSweeney, 2003). The differences among treatments in $\alpha_{\mathrm{S} 1}-\mathrm{CN}$ concentration may be due to differences among treatments in urea supply to the small intestine. This is because the supply of AA and urea to the small intestine can alter the protein composition in milk. Hermansen et al. (1999) found that the concentration of $\alpha_{\mathrm{S}_{1}} \mathrm{CN}$ decreased with increasing supply of AA and urea. Amino acid and urea supply to the small intestine can increase with increasing dietary CP concentration (Hristov et al., 2004). We also observed an effect of treatment on the concentration of $\beta$-LG. $\beta$-Lactoglobulin is the most abundant whey protein, accounting for approximately $58 \%$ of total whey protein (Hogarth et al., 2004). Of all of the milk proteins, $\beta$-LG has the greatest effect on some processing characteristics, such as HCT (Singh, 2004). The HCT or heat stability of milk refers to the ability to withstand high processing temperatures without visible coagulation or gelation (Singh, 2004) and is an important variable in the milk-processing sector (Sikand et al., 2010). Milk protein composition can influence the HCT of skim milk across a pH range (Tessier and Rose, 1964). Increased blood albumin concentration has been associated with a reduction in the concentrations of the whey proteins, such as $\beta-\mathrm{LG}$, in milk (Gray and Mackenzie, 1987). In the present study, the lowest concentration of $\beta-\mathrm{LG}$ was observed in HPrHP, which had the highest blood albumin concentration. Treatment HPrHP had the lowest HCT and the lowest concentration of $\beta$-LG. In addition, MPrHP had the highest HCT and the highest concentration of $\beta$-LG.

The HCT of milk is affected by several factors, of which $\mathrm{pH}$ is the most important (Singh, 2004). The pH range used in the present study was selected because it is the typical bovine milk $\mathrm{pH}(6.6-6.8)$ and accounts for the variability that can be associated with quality and heating effect (Walstra and Jenness, 1984). In a $\mathrm{pH}$ range of 6.2 to 6.7 , heat coagulation occurs rapidly due to the high activity of $\mathrm{Ca}$ ions at this $\mathrm{pH}$ (Fox, 1981). In the $\mathrm{pH}$ range of 6.7 to 7.4 , Ca ion activity is reduced, which delays the onset of heat coagulation; however, other factors also play a role in HCT (Crowley et al., 2014). During the process of heat treatment, urea is broken down to form ammonia. Ammonia, at a $\mathrm{pH}$ greater than 6.7, can stabilize milk due to its buffering nature. This was demonstrated by Crowley et al. (2014), who showed that in the $\mathrm{pH}$ range of 6.9 to 7.4 HCT increased with increasing concentrations of milk urea in reconstituted milk protein concentrates; this effect of milk urea on HCT was not apparent at lower $\mathrm{pH}$. The present study found a significant positive correlation between MUN concentration and $\mathrm{HCT}$ at $\mathrm{pH}$ 7.4. At $\mathrm{pH} 6.8$, the MPrHP had the greatest HCT; however, at a $\mathrm{pH}$ of 7.4 , there was no difference among treatments. This can be explained by the sharp increase in HCT of HPrHP from $\mathrm{pH} 7.2$ to 7.4, which resulted in a significant positive relationship between MUN and HCT at the $\mathrm{pH}$ of 7.4.

\section{Phosphorus}

The dietary $\mathrm{P}$ concentrations in the present study were $0.37,0.31$, and $0.33 \%$ in HPrHP, MPrHP, and LPrHP treatments, respectively, and $0.22 \%$ in LPrLP. Grass P concentrations were lower than anticipated, resulting in lower dietary $\mathrm{P}$ concentrations than formulated. The recommended dietary $\mathrm{P}$ concentration is 0.35 to $0.40 \%$ (NRC, 2001). Dietary P concentration had no effect on milk yield or milk solids yield. Milk fat and protein concentrations were also unaffected by dietary P. Call et al. (1987) offered dietary P concentrations of $0.24 \% \mathrm{DM}$ and $0.32 \% \mathrm{DM}$ to dairy cows for $1 \mathrm{yr}$. Six weeks postcalving, a reduction in feed intake was observed in the $0.24 \%$ DM P treatment, followed by a reduction in milk protein concentration. Eighteen weeks into lactation, the $0.24 \%$ DM P treatment significantly reduced milk yield. Valk and Šebek (1999) observed no difference in milk protein concentration when dietary $\mathrm{P}$ concentrations of $0.24,0.28$, or $0.33 \%$ DM were offered to dairy cows over 2 yr. However, in the second year of the study, a difference in milk yield was observed. The $0.24 \%$ DM P treatment had a significantly lower milk yield than the 0.28 and $0.33 \%$ DM P treatments. Ferris et al. (2010) conducted a study in which dietary $\mathrm{P}$ concentrations of $0.49 \% \mathrm{DM}$ and $0.36 \% \mathrm{DM}$ were offered to dairy cows over 4 successive lactations. No difference between treatments was observed in milk yield 
or composition. It is likely that the short-term nature of the present study prevented the negative effects of low dietary $\mathrm{P}$ concentration on feed intake, milk yield, and milk composition being observed.

We detected an effect of dietary $\mathrm{P}$ on BUN, which was unexpected. Although there were statistically significant differences among treatments, the BUN values for all 4 treatments were within the normal range (Mee and Nolan, 1994) and therefore the differences may not be of biological significance.

Cows in the LPrLP treatment had significantly lower blood $\mathrm{P}$ concentrations compared with those in the other 3 treatments. Blood P in cows in the LPrLP treatment decreased below the recommended level of $1.1 \mathrm{mmol} / \mathrm{L}$ (NRC, 2001). Stage of lactation has an effect on blood P concentration. Wu et al. (2001) found that blood $\mathrm{P}$ concentration in cows decreased from calving until approximately $11 \mathrm{wk}$ postcalving and then increased as lactation progressed. The cows in the present study were 4 wk into lactation at the beginning of the study and 13 wk into lactation at the end of the study. They were thus at the lowest point of the lactation curve for blood P concentration. The LPrLP blood $\mathrm{P}$ concentration of $0.79 \mathrm{mmol} / \mathrm{L}$ (measured at the end of the study) was similar to that found by Valk et al. (2002), who observed a blood P concentration of 0.8 $\mathrm{mmol} / \mathrm{L}$ when a dietary $\mathrm{P}$ concentration of $0.24 \mathrm{~g} / \mathrm{kg}$ of DM was offered, although they only measured blood $\mathrm{P}$ concentration in cows during their second lactation at this dietary $\mathrm{P}$ level. Blood $\mathrm{P}$ concentration has been positively related to dietary $\mathrm{P}$ concentration in several studies (Dhiman et al., 1995; Wu and Satter, 2000; Lopez et al., 2004). In the present study, the HPrHP, MPrHP, and LPrHP treatments had greater concentrations of dietary $\mathrm{P}$ than the LPrLP treatment, which was reflected in the blood $\mathrm{P}$ concentration.

Conducting the present study in early lactation increased the likelihood of measuring an increase in fecal $\mathrm{P}$ excretion when a high dietary $\mathrm{P}$ concentration was offered to cows compared with a low dietary $\mathrm{P}$ concentration. In mid and late lactation, excess $\mathrm{P}$ is deposited in bone, rather than excreted, in order to replenish bone reserves mobilized in early lactation ( $\mathrm{Wu}$ et al., 2001). In early lactation, however, the excess $\mathrm{P}$ is excreted (Wu et al., 2001). In the present study, daily fecal P excretion was significantly lower in the LPrLP treatment compared with the other 3 treatments. This agrees with Valk et al. (2002) and Ferris et al. (2010), who also found that daily fecal $\mathrm{P}$ excretion was reduced when a lower dietary P concentration was offered.

Ruminants have a well-developed capacity for conserving $\mathrm{P}$, and normally very little $\mathrm{P}$ is excreted in the urine, even with a very high dietary P intake (Ternouth, 1990). Urine only becomes a significant excretory route for $\mathrm{P}$ when diets contain excessively high concentrations of P (Ferris et al., 2010), which was not the case in the present study. Therefore, the lack of an effect of treatment on urinary $\mathrm{P}$ excretion in the present study is not surprising.

The $\mathrm{P}$ and Ca concentrations of the composite milk were within the range reported by other studies (Hallén et al., 2010; Frederiksen et al., 2011). Besides CN and whey proteins, $\mathrm{P}$ and $\mathrm{Ca}$ are essential constituents of CN micelles (Malacarne et al., 2014). Higher concentrations of milk $\mathrm{P}$ and $\mathrm{Ca}$ are indicative of better milk-processing characteristics such as milk coagulation ability (Malacarne et al., 2014). Increased concentrations of $\mathrm{P}$ in milk have been associated with an increase in CN concentration (Malacarne et al., 2014). A relationship also exists in the concentration of milk protein and milk P concentration (Wu and Satter, 2000). Klop et al. (2013) conducted a review of studies $(\mathrm{n}=42)$ in which dietary $\mathrm{P}$ concentration, milk $\mathrm{P}$ concentration, and fecal $\mathrm{P}$ excretion were reported. They found no relationship between DMI, dietary $\mathrm{P}$ concentration, or total $\mathrm{P}$ intake and the concentration of $\mathrm{P}$ in milk. They also found no effect of milk yield on milk $\mathrm{P}$ concentration. The results of the present study agree with the review of Klop et al. (2013), in which dietary P did not affect the concentration of $\mathrm{P}$ in the composite milk samples. The lack of an effect of dietary $\mathrm{P}$ on milk $\mathrm{P}$ concentration may help to explain why dietary $\mathrm{P}$ concentration did not affect milk $\mathrm{N}$ fractions, milk protein composition, or HCT.

\section{CONCLUSIONS}

This study quantified the difference in milk heat stability, MUN concentration, and $\mathrm{N}$ and $\mathrm{P}$ utilization when supplementing grazing dairy cows with concentrates differing in $\mathrm{CP}$ and $\mathrm{P}$ concentrations. Supplementing cows with a high $\mathrm{CP}$ concentrate increased MUN concentration and reduced the heat stability of the milk at $\mathrm{pH} 6.8$, both of which are negative from a milk processing perspective. Offering a low $\mathrm{P}$ concentrate had no effect on milk $\mathrm{P}$ concentration or milk heat stability, but did reduce total $\mathrm{P}$ excretion. Blood $\mathrm{P}$ was reduced, however, below the recommended level. This experiment served as an opportunity to measure the effect of dairy cow diet on the suitability of milk for processing, while increasing knowledge on the effect of dairy cow diet on nutrient use efficiency.

\section{ACKNOWLEDGMENTS}

The authors thank and acknowledge the Moorepark farm management and staff for their assistance during the study and the Moorepark laboratory staff for the 
analysis carried out. The work of placement students based at the Moorepark farm during the experiment is also greatly appreciated. The first author was funded by the Teagasc Walsh Fellowship scheme. This study was funded by the Department of Agriculture, Food and the Marine (Dublin, Ireland) Stimulus fund (11/ sf/309).

\section{REFERENCES}

Bargo, F., L. Muller, J. Delahoy, and T. Cassidy. 2002. Milk response to concentrate supplementation of high producing dairy cows grazing at two pasture allowances. J. Dairy Sci. 85:1777-1792.

Bargo, F., L. Muller, E. Kolver, and J. Delahoy. 2003. Invited review: Production and digestion of supplemented dairy cows on pasture. J. Dairy Sci. 86:1-42.

Borucki Castro, S. I., L. Phillip, H. Lapierre, P. Jardon, and R. Berthiaume. 2008. The relative merit of ruminal undegradable protein from soybean meal or soluble fiber from beet pulp to improve nitrogen utilization in dairy cows. J. Dairy Sci. 91:3947-3957.

Broderick, G. A. 2003. Effects of varying dietary protein and energy levels on the production of lactating dairy cows. J. Dairy Sci. 86:1370-1381.

Burgos, S. A., J. Fadel, and E. DePeters. 2007. Prediction of ammonia emission from dairy cattle manure based on milk urea nitrogen: Relation of milk urea nitrogen to urine urea nitrogen excretion. J. Dairy Sci. 90:5499-5508.

Burke, F., M. A. O'Donovan, J. J. Murphy, F. P. O'Mara, and F. J. Mulligan. 2008. Effect of pasture allowance and supplementation with maize silage and concentrates differing in crude protein concentration on milk production and nitrogen excretion by dairy cows. Livest. Sci. 114:325-335.

Call, J. W., J. Butcher, J. Shupe, R. Lamb, R. Boman, and A. Olson. 1987. Clinical effects of low dietary phosphorus concentrations in feed given to lactating dairy cows. Am. J. Vet. Res. 48:133-136.

Castillo, A. 2001. The effect of protein supplementation on nitrogen utilization in lactating dairy cows fed grass silage diets. PhD Thesis. The University of Reading, Reading, UK.

Crowley, S., M. Megemont, I. Gazi, A. Kelly, T. Huppertz, and J. O'Mahony. 2014. Heat stability of reconstituted milk protein concentrate powders. Int. Dairy J. 37:104-110. http://dx.doi. org/10.1016/j.idairyj.2014.03.005.

Curran, J., L. Delaby, E. Kennedy, J. P. Murphy, T. M. Boland, and M. O'Donovan. 2010. Sward characteristics, grass dry matter intake and milk production performance are affected by pre-grazing herbage mass and pasture allowance. Livest. Sci. 127:144-154.

DAFM. 2013. Annual Fertiliser Use Statistics. Department of Agriculture, Food and the Marine, Dublin, Ireland.

Dalgleish, D. 1993. The enzymatic coagulation of milk. Vol. 1. Cheese: Chemistry, Physics and Microbiology. Elsevier Academic Press, Amsterdam, the Netherlands.

Davies, D., and J. White. 1966. The stability of milk protein to heat. J. Dairy Res. 33:67-71.

DePeters, E. J., and J. D. Ferguson. 1992. Nonprotein nitrogen and protein distribution in the milk of cows. J. Dairy Sci. 75:31923209.

Dhiman, T., L. Satter, and R. Shaver. 1995. Milk production and blood phosphorus concentrations of cows fed low and high dietary phosphorus. Research Summaries. US Dairy Forage Research Center, Madison, WI.

Dillon, P., S. Crosse, and B. O'Brien. 1997. Effect of concentrate supplementation of grazing dairy cows in early lactation on milk production and milk processing quality. Ir. J. Agric. Food Res. 36:145-159.

Dillon, P., T. Hennessy, L. Shalloo, F. Thorne, and B. Horan. 2008. Future outlook for the Irish dairy industry: A study of international competitiveness, influence of international trade reform and requirement for change. Int. J. Dairy Technol. 61:16-29.
Dillon, P., and G. Stakelum. 1989. Herbage and dosed alkanes as a grass measurement technique for dairy cows. Isr. J. Agric. Res. 28:104. (Abstr.)

Edmonson, A., I. Lean, L. Weaver, T. Farver, and G. Webster. 1989. A body condition scoring chart for Holstein dairy cows. J. Dairy Sci. $72: 68-78$.

Farrell, H. M. Jr., R. Jimenez-Flores, G. Bleck, E. Brown, J. Butler, L. Creamer, C. Hicks, C. Hollar, K. Ng-Kwai-Hang, and H. Swaisgood. 2004. Nomenclature of the proteins of cows' milk-Sixth revision. J. Dairy Sci. 87:1641-1674.

Ferris, C. P., D. C. Patterson, M. A. McCoy, and D. J. Kilpatrick. 2010. Effect of offering dairy cows diets differing in phosphorus concentration over four successive lactations: 2. Health, fertility, bone phosphorus reserves and nutrient utilisation. Animal 4:560-571.

Finneran, E., P. Crosson, P. O'Kiely, L. Shalloo, D. Forristal, and M. Wallace. 2010. Simulation modelling of the cost of producing and utilising feeds for ruminants on Irish farms. J. Farm Mgmt. 14:95-116.

Forster, R. J., D. G. Grieve, J. G. Buchanan-Smith, and G. K. Macleod. 1983. Effect of dietary protein degradability on cows in early lactation. J. Dairy Sci. 66:1653-1662.

Fox, P. 1981. Heat-induced changes in milk preceding coagulation. J. Dairy Sci. 64:2127-2137.

Fox, P., and P. McSweeney. 2003. Advanced Dairy Chemistry. Vol. 1: Proteins. Kluwer Academic/Plenum, New York, NY.

Frederiksen, P. D., K. Andersen, M. Hammershøj, H. Poulsen, J Sørensen, M. Bakman, K. Qvist, and L. Larsen. 2011. Composition and effect of blending of noncoagulating, poorly coagulating, and well-coagulating bovine milk from individual Danish Holstein cows. J. Dairy Sci. 94:4787-4799.

Gray, R., and D. Mackenzie. 1987. Effect of plane of nutrition on the concentration and yield of whey proteins in bovine milk. N. Z. J. Dairy Sci. 22:157-165.

Guyomarc'h, F., O. Mahieux, M. Renan, M. Chatriot, V. Gamerre, and M. H. Famelart. 2007. Changes in the acid gelation of skim milk as affected by heat-treatment and alkaline $\mathrm{pH}$ conditions. Lait 87:119-137.

Hallén, E., A. Lundén, A.-M. Tyrisevä, M. Westerlind, and A. Andrén. 2010. Composition of poorly and non-coagulating bovine milk and effect of calcium addition. J. Dairy Res. 77:398-403.

Hermansen, J. E., S. Ostersen, C. Justesen, and O. Aaes. 1999. Effects of dietary protein supply on caseins, whey proteins, proteolysis and renneting properties in milk from cows grazing clover or $\mathrm{N}$ fertilized grass. J. Dairy Res. 66:193-205.

Hogarth, C. J., J. L. Fitzpatrick, A. M. Nolan, F. J. Young, A. Pitt, and P. D. Eckersall. 2004. Differential protein composition of bovine whey: A comparison of whey from healthy animals and from those with clinical mastitis. Proteomics 4:2094-2100.

Hristov, A. N., R. Etter, J. Ropp, and K. Grandeen. 2004. Effect of dietary crude protein level and degradability on ruminal fermentation and nitrogen utilization in lactating dairy cows. J. Anim. Sci. 82:3219-3229.

IDF. 2001. Milk-Determination of nitrogen content-Part 4: Block digestion method (semi-micro rapid routine method). Standard 203. International Dairy Federation, Brussels, Belgium.

IDF. 2004a. Milk-Determination of casein-nitrogen content-Part 1 indirect method (reference method). Standard 29-1. International Dairy Federation, Brussels, Belgium.

IDF. 2004b. Milk-Determination of nitrogen content-Part 3: Block digestion method (semi-micro rapid routine method). Standard 203. International Dairy Federation, Brussels, Belgium.

INRA. 1989. Ruminant Nutrition: Recommended Allowances and Feed Tables. INRA Editions, Paris, France.

Kauffman, A. J., and N. St-Pierre. 2001. The relationship of milk urea nitrogen to urine nitrogen excretion in Holstein and Jersey cows. J. Dairy Sci. 84:2284-2294.

Kennedy, E., J. Curran, B. Mayes, M. McEvoy, J. Murphy, and M. O'Donovan. 2011. Restricting dairy cow access time to pasture in early lactation: The effects on milk production, grazing behaviour and dry matter intake. Animal 5:1805-1813. 
Kennedy, E., M. O'Donovan, L. Delaby, and F. P. O'Mara. 2008. Effect of herbage allowance and concentrate supplementation on dry matter intake, milk production and energy balance of early lactating dairy cows. Livest. Sci. 117:275-286.

Klop, G., J. Ellis, A. Bannink, E. Kebreab, J. France, and J. Dijkstra. 2013. Meta-analysis of factors that affect the utilization efficiency of phosphorus in lactating dairy cows. J. Dairy Sci. 96:3936-3949.

Kung, L. Jr., and J. T. Huber. 1983. Performance of high producing cows in early lactation fed protein of varying amounts, sources, and degradability. J. Dairy Sci. 66:227-234.

Law, R. A., F. Young, D. Patterson, D. Kilpatrick, A. Wylie, and C. Mayne. 2009. Effect of dietary protein content on animal production and blood metabolites of dairy cows during lactation. J. Dairy Sci. 92:1001-1012.

LeBlanc, S. 2010. Monitoring metabolic health of dairy cattle in the transition period. J. Reprod. Dev. 56:S29-S35.

Leonardi, C., M. Stevenson, and L. Armentano. 2003. Effect of two levels of crude protein and methionine supplementation on performance of dairy cows. J. Dairy Sci. 86:4033-4042.

Lopez, H., Z. Wu, L. Satter, and M. Wiltbank. 2004. Effect of dietary phosphorus concentration on estrous behavior of lactating dairy cows. Theriogenology 61:437-445.

Malacarne, M., P. Franceschi, P. Formaggioni, S. Sandri, P. Mariani, and A. Summer. 2014. Influence of micellar calcium and phosphorus on rennet coagulation properties of cows milk. J. Dairy Res. 81:129-136.

Mayes, R., C. Lamb, and P. M. Colgrove. 1986. The use of dosed and herbage n-alkanes as markers for the determination of herbage intake. J. Agric. Sci. 107:161-170.

Mee, J., and M. Nolan. 1994. Summer mini-metabolic profile of 50 spring-calving dairy herds. Pages 40-41 in Moorepark Research and Development Division Research Report. Teagasc, Moorepark, Ireland.

Morgan, D., and G. Stakelum. 1987. The prediction of the digestibility of herbage for dairy cows. Isr. J. Agric. Res. 26:23-34.

Mounsey, J. S., and B. T. O'Kennedy. 2009. Stability of $\beta$-lactoglobulin/ micellar casein mixtures on heating in simulated milk ultrafiltrate at pH 6.0. Int. J. Dairy Technol. 62:493-499.

Mulligan, F. J., P. Dillon, J. J. Callan, M. Rath, and F. P. O'Mara. 2004. Supplementary concentrate type affects nitrogen excretion of grazing dairy cows. J. Dairy Sci. 87:3451-3460.

NRC. 2001. Nutrient Requirements of Dairy Cattle. 7th rev. ed. National Academies Press, Washington, DC.

O’Neill, B., E. Lewis, M. O'Donovan, L. Shalloo, F. Mulligan, T. Boland, and R. Delagarde. 2013. Evaluation of the GrazeIn model of grass dry matter intake and milk yield for temperate grass-based production systems. 1. Sward characteristics and grazing management factors. Grass Forage Sci. 68:504-523.

Olmos Colmenero, J. J., and G. A. Broderick. 2006. Effect of dietary crude protein concentration on milk production and nitrogen utilization in lactating dairy cows. J. Dairy Sci. 89:1704-1712.

Pérez-Prieto, L. A., and R. Delagarde. 2012. Meta-analysis of the effect of pregrazing pasture mass on pasture intake, milk production, and grazing behavior of dairy cows strip-grazing temperate grasslands. J. Dairy Sci. 95:5317-5330.

SAS Institute. 2005. SAS User's Guide: Statistics. ver. 9.1. SAS Institute Inc., Cary, NC.

Satter, L. 2003. Phosphorus management in cattle production systems. Pages 157-174 in Proc. Nottingham Feed Manufacturers Conference. Nottingham University Press, Nottingham, UK.

Schulte, R., and S. Lalor. 2007. Phosphorus for grassland: Agronomically and environmentally sustainable advice. Page 36 in Proc. Fertiliser Association of Ireland, Dublin.
Sikand, V., P. Tong, and J. Walker. 2010. Heat stability of reconstituted, protein-standardized skim milk powders. J. Dairy Sci. 93:5561-5571.

Singh, H. 2004. Heat stability of milk. Int. J. Dairy Technol. 57:111119

Smith, K. A., D. Jackson, and P. Withers. 2001. Nutrient losses by surface run-off following the application of organic manures to arable land. 2. Phosphorus. Environ. Pollut. 112:53-60.

Spek, J. W., J. Dijkstra, G. Van Duinkerken, and A. Bannink. 2012. A review of factors influencing milk urea concentration and its relationship with urinary urea excretion in lactating dairy cattle. J. Agric. Sci. 1:1-17.

Spek, J. W., J. Dijkstra, G. van Duinkerken, W. Hendriks, and A. Bannink. 2013. Prediction of urinary nitrogen and urinary urea nitrogen excretion by lactating dairy cattle in Northwestern Europe and North America: A meta-analysis. J. Dairy Sci. 96:4310-4322.

Steinshamn, H., M. Höglind, T. H. Garmo, E. Thuen, and U. T. Brenøe. 2006. Feed nitrogen conversion in lactating dairy cows on pasture as affected by concentrate supplementation. Anim. Feed Sci. Technol. 131:25-41.

Stockdale, C. 1995. Maize silage as a supplement for pasture-fed dairy cows in early and late lactation. Anim. Prod. Sci. 35:19-26.

Ternouth, J. 1990. Phosphorus and beef production in northern Australia. 3. Phosphorus in cattle-A review. Trop. Grassl. 24:159 169

Tessier, H., and D. Rose. 1964. Influence of $\kappa$-casein and $\beta$-lactoglobulin on the heat stability of skimmilk. J. Dairy Sci. 47:1047-1051.

Tyrrell, H. F., and J. Reid. 1965. Prediction of the energy value of cow's milk. J. Dairy Sci. 48:1215-1223.

Valadares, R. F., G. Broderick, and M. Clayton. 1999. Effect of replacing alfalfa silage with high moisture corn on ruminal protein synthesis estimated from excretion of total purine derivatives. J. Dairy Sci. 82:2686-2696.

Valk, H., and L. Šebek. 1999. Influence of long-term feeding of limited amounts of phosphorus on dry matter intake, milk production, and body weight of dairy cows. J. Dairy Sci. 82:2157-2163.

Valk, H., L. B. J. Šebek, and A. C. Beynen. 2002. Influence of phosphorus intake on excretion and blood plasma and saliva concentrations of phosphorus in dairy cows. J. Dairy Sci. 85:2642-2649.

Van Soest, P. J., J. Robertson, and B. Lewis. 1991. Methods for dietary fiber, neutral detergent fiber, and nonstarch polysaccharides in relation to animal nutrition. J. Dairy Sci. 74:3583-3597.

van Vuuren, A., C. Van der Koelen, H. Valk, and H. De Visser. 1993. Effects of partial replacement of ryegrass by low protein feeds on rumen fermentation and nitrogen loss by dairy cows. J. Dairy Sci. 76:2982-2993.

Walstra, P., and R. Jenness. 1984. Dairy Chemistry and Physics. John Wiley \& Sons, Hoboken, NJ.

Whelan, S. J., K. Pierce, C. McCarney, B. Flynn, and F. Mulligan. 2012. Effect of supplementary concentrate type on nitrogen partitioning in early lactation dairy cows offered perennial ryegrassbased pasture. J. Dairy Sci. 95:4468-4477.

Wu, Z., L. Satter, A. Blohowiak, R. Stauffacher, and J. Wilson. 2001. Milk production, estimated phosphorus excretion, and bone characteristics of dairy cows fed different amounts of phosphorus for two or three years. J. Dairy Sci. 84:1738-1748.

Wu, Z., and L. D. Satter. 2000. Milk production and reproductive performance of dairy cows fed two concentrations of phosphorus for two years. J. Dairy Sci. 83:1052-1063. 